\title{
Impact of landfill leachate on the germination of Cucumber (Cucumis sativus)
}

\author{
Heider Alves Franco ${ }^{1}$, Maria Eduarda Rocha Valente da Silva ${ }^{2}$, Millena Ferreira da Silveira ${ }^{3}$ \\ Monica Regina da Costa Marques ${ }^{4}$ and Sérgio Thode Filho ${ }^{5}$
}

\author{
${ }^{1}$ Professor at the Federal Institute of Education, Science and Technology of Rio de Janeiro - IFRJ, Campus Pinheiral, RJ, \\ Multidisciplinary Laboratory of Agro-Environmental Technology - LAMTAA. heider.franco@ifrj.edu.br \\ 2,3Student of the Technical Course in Environment - IFRJ, Campus Pinheiral, RJ, Multidisciplinary Laboratory of Agro- \\ Environmental Technology - LAMTAA \\ ${ }^{4}$ Professor at the State University of Rio de Janeiro - UERJ, Environmental Technology Laboratory - LABTAM \\ 5Professor at the Federal Institute of Education, Science and Technology of Rio de Janeiro - IFRJ, Campus Duque de \\ Caxias, RJ, Multidisciplinary Laboratory Waste Management - LMGR
}

\begin{abstract}
The generation of landfill leachate occurs due to the degradation of solid waste by the presence of microorganisms. The bioassays allow to understand the relationship between the medium and the leachate, determining the lethal concentration capable of inhibiting $50 \%$ of test organisms (LC50), the lowest concentration with observed deleterious effect (LOEC), and the highest concentration without observed deleterious effect (NOEC). This work aimed to determine the impact of landfill leachate on germination and development of radicle and aerial part of cucumber (Cucumis sativus) on two substrates. The design was completely randomized and 6 treatments with increasing doses (leachate + deionized water): $\mathrm{T} 1=3.125 \%+96.875 \% ; \mathrm{T} 2=6.25 \%+93.75 \% ; \mathrm{T} 3=12.5 \%+87.5 \% ; \mathrm{T} 4=25 \%+75 \% ; \mathrm{T} 5=50 \%+50 \%$ and $\mathrm{T} 6=100 \%$ leached, and the control (TC) with 100\% deionized water, both in triplicates for filter and soil paper substrates. Cucumber tolerance to leachate was identified. It was not possible to determine the LC50 from the treatments, however the $50 \%$ and $100 \%$ doses inhibited the germination by $83 \%$ and $100 \%$, and the NOEC and LOEC values were identified in treatments $12.5 \% / 25 \%$ and $25 \% / 50 \%$ on filter paper and soil, respectively.
\end{abstract}

Keywords: Landfill leachate, Environmental impact, Lethal Concentration, Bioassays.

\section{Introduction}

The intense generation of urban solid waste (USW) presents a risk situation due to the generation of leachate. After the promulgation of the National Policy on Solid Waste, the environmentally correct disposal of USW is the sanitary landfill, but this one has as levied leachate that accumulates in open tanks. Due to the complex and heterogeneous characteristics 
of USW, such as organic matter (paper, cardboard, wood branches) and inert materials (plastics, glass, metal, etc.) (CARVALHO et al., 2006).

Special attention should be given to the leachate generated in landfills, as it is a potentially polluting liquid that can attack nearby natural resources if it is not treated and discarded in a careful and controlled way (SALEM et al. 2008).

The generation of leachate occurs due to the degradation of solid residues by the presence of microorganisms, most of them bacteria acting on aerobic or anaerobic metabolism, characterized by the existence and absence of oxygen, respectively; Besides these, the environmental conditions, characteristic of the residues and precipitation contribute to a greater or lesser volume of leachate (IPT, 1995).

For landfill leachates, several treatment methods have been studied. Omar and Rohani (2015) discussed a wide review on the subject, presenting methodology, advantages and disadvantages. According to the authors, there is a need to expand knowledge in all aspects about landfills.

The characterization of landfill leachate identifies and quantifies the chemical substances and physical characteristics of the landfill. However it is not possible to infer its direct impact on the ecosystem. For this, it is necessary to use bioassays or biotests of phytotoxicity that are presented as an important tool in the study of the relationship between living beings and the chemical components of the environment in which they are inserted and the genotypic, physiological and morphological consequences of this interaction. These tests can be used for environmental monitoring (DE SERES, 1978, apud FISKEJO, 1985), studies of the contamination of ecosystems, allelopathy, amongst others.

There are laboratory tests carried out under specific and controlled experimental conditions, aiming at estimating the toxicity of substances, agricultural, industrial and domestic effluents, medicines, chemicals in general and environmental samples (water or sediments), as well as evaluating the resulting synergistic effects and antagonists (FLOHR et al., 2005; COSTA, et al., 2008).

Germination bioassays with plants are advantageous, since they are sensitive to several chemical compounds, such as pesticides, soil samples and organic substances amongst others (STEINKELLNER et al., 1998). Further advantages are the ease of storage and manipulation of plants, good chromosomal conditions, good correlation with other types of tests (FISKESJÖ, 1985), relatively simple methodologies, good reproducibility and repetition, fast results and low costs (LOPEZ et al., 2008).

For this, bioassays are performed in different test organisms. Germination tests are performed to determine the potential effect of a pollutant. To assess the concentration / lethal dose capable of causing death or inhibition in $50 \%$ of test organisms (LC50), it is also possible to determine the lowest concentration where the pollutant effect is observed (LOEC), as well as the highest concentration in which no deleterious effect (NOEC) (ADAMS et al., 2002; RONCO; BAEZ e GRANADOS, 2004).

The Organization for Economic Cooperation and Development (OECD), lists a species list for this type of trial, among which is cucumber (Cucumis sativus) (OECD, 2003). In view of this, the present work aims to determine the impact potential impact of landfill leachate on the germination and development of radicle and aerial part of cucumber (Cucumis sativus). 


\section{Material and methods}

\subsection{Materials}

The implantation and conduction of the tests took place in the Multidisciplinary Laboratory of Agro-Environmental Technology (LAMTAA) of Pinheiral Campus of the Federal Institute of Rio de Janeiro, located in the municipality of Pinheiral-RJ, geographical coordinates $22^{\circ} 31^{\prime} 12.57^{\prime \prime S}$ and $43^{\circ} 59^{\prime} 30.61^{\prime \prime} \mathrm{W}$. The physico-chemical characterization of the landfill leachate was carried out at the Laboratory of Environmental Technology of the State University of Rio de Janeiro (LABTAM-UERJ).

The landfill leachate used in the study was provided by the company Haztec Tecnologia e Planejamento Ambiental S.A., which manages the Waste Treatment Center (WTC) located in the city of Barra Mansa, with geographic coordinates $22^{\circ} 35^{\prime} 11.52^{\prime \prime} \mathrm{S}$ and $44^{\circ} 12^{\prime} 54.31^{\prime \prime} \mathrm{W}$.

The planning, compilation and maintenance of the leachate were performed according to NBR 9897 (ABNT, 1987). The leachate was stored in a plastic container with 50 liter capacity and $25 \%$ of its contents were renewed monthly to avoid losing its characteristics. Seeds of Pepino (Cucumis sativus) cultivar Verde Comprido, from the company Isla seeds, whose germination potential was around $85 \%$ were used. Petri dish $(9.5 \mathrm{~cm}$ diameter) and substrate qualitative filter paper $(1 \mu \mathrm{m}$ porosity) were used for direct impact testing. And, for the indirect impact test, the substrate used was a Planosol Hapless Tb Eutrophic of sandy texture. To guarantee the environmental conditions, the containers were placed in a germ chamber of type BOD with photoperiod of the brand Thelga model TF34.

\subsection{Methods}

\subsubsection{Physical-chemical characterization of landfill leachate.}

The physicochemical characterization was performed according to the method of the American Public Health Association (APHA, 2005). The following parameters were characterized: electrical conductivity (EC), $\mathrm{pH}$ and total dissolved solids (TDS), through direct reading of a waterproof multiparameter PCS Testr 35; and chemical oxygen demand (COD) using the closed reflux colorimetric method of digestion of the samples with a Tecnal TE-021 dry block digester, followed by reading the samples in a Hach DR 5000 spectrophotometer.

The determination of cations and anions was performed by ion chromatography. Samples of landfill leachate were diluted 1000 times and then filtered with syringes coupled to fiberglass filters with $0.22 \mu \mathrm{m}$ pore size to avoid clogging with particulate matter. The filtered material was placed in vials of a Dionex ICs 3000 ion chromatography system. The apparatus was equipped with an IonPac CS16 analytical column $(3.0 \times 250 \mathrm{~mm})$ preceded by two pre-columns. The cation suppressor used was 300 CSRS $(2.0 \mathrm{~mm})$. The equipment also has an IonPac AS 23 analytical column $(2.0 \times 250 \mathrm{~mm})$ preceded by a guard column and an anion suppressor (SRS 2 $\mathrm{mm}$ ). In the mobile phase testing, the cations used for detection were methyl sulfonic acid (MSA) injected into the column at a concentration of $32 \mathrm{mmol} \mathrm{L}^{-1}$. For anions, we used solutions of carbonate/sodium bicarbonate at concentrations of $4.5 \mathrm{mmol} \mathrm{L}^{-1}$ and $0.8 \mathrm{mmol} \mathrm{L}^{-1}$.

For determination of the metal concentrations ( $\mathrm{Al}, \mathrm{Cd}, \mathrm{Cr}, \mathrm{Cu}, \mathrm{Fe}, \mathrm{Mn}, \mathrm{Ni}, \mathrm{Pb}$ and $\mathrm{Zn}$ ), samples were digested according to the USEPA procedure (1998): $20.0 \mathrm{~mL}$ of sample and $10.0 \mathrm{ml}$ 
of nitric acid $\left(\mathrm{HNO}_{3}\right)$ PA were placed in a Teflon bottle which was then closed and heated in a microwave oven (Milestone Start E) with a power of $600 \mathrm{~W}$ for $20 \mathrm{~min}$ (heating to $170{ }^{\circ} \mathrm{C}$ for 10 minutes and maintained at $170{ }^{\circ} \mathrm{C}$ for 10 minutes). The product obtained was passed through filter paper and swelled in $100 \mathrm{ml}$ flat-bottom volumetric flasks. Samples were read in duplicate with a Varian 240 ASA flame atomic absorption spectrometer. The operating conditions used in the FAAS were exposure time of 5 minutes, air-acetylene flame; airflow of $10.0 \mathrm{~L} \mathrm{~min}^{-1}$, and acetylene flow of $2.0 \mathrm{~L} \mathrm{~min}^{-1}$ (Table 1$)$.

\subsubsection{Effect on germination and development of Cucumber (Cucumis sativus) roots - direct impact.}

The experimental dynamics followed a completely randomized design developed in two groups: test and control. For the test group, six treatments were applied with increasing doses in a ratio of 50\% of landfill leachate, as follows (Aragão et al., 2008 Almeida et al., 2011.): $\mathrm{T} 1=3.125 \%$ leachate $+96.875 \%$ deionized water; $\mathrm{T} 2=6.25 \%$ leachate $+93.75 \%$ deionized water; $\mathrm{T} 3=12.5 \%$ leachate $+87.5 \%$ deionized water; $\mathrm{T} 4=25 \%$ leachate $+75 \%$ deionized water; $\mathrm{T} 5=50 \%$ leachate + $50 \%$ deionized water; T6 $=100 \%$ leachate; and control $(\mathrm{TC})=100 \%$ deionized water. All treatments were performed in triplicate.

In conducting the study, 20 seeds of cucumber (Cucumis sativus) were divided in Petri dishes ( $9.5 \mathrm{~cm}$ in diameter) with qualitative filter paper substrate (porosity $1 \mu \mathrm{m}$ ) and moistened with $4.0 \mathrm{ml}$ of the sample solutions. To ensure moisture throughout the test, the Petri dishes were wrapped with transparent parafilm and later placed in a germination chamber at temperature $\left(25 \pm 2^{\circ} \mathrm{C}\right)$; photoperiod (12 hours light / 12 hours dark) and total run time of 168 hours (BRASIL, 2009). These conditions were obtained with the use of a Thelga TF34 BOD chamber, where the container dishes were prepared.

\subsubsection{Effect on germination and development of Cucumber (Cucumis sativus) - indirect impact.}

For this assay the methodology of Lopes (2010) was adapted, where $50 \mathrm{~mL}$ plastic containers were filled with $50 \mathrm{~g}$ of sandy soil moistened with $17.5 \mathrm{~mL}$ of solution (landfill leachate + deionized water), according to the same treatments applied in the direct impact test. Seeds were then sown where 10 (ten) cucumber seeds were placed at diametrically equal distances above the soil. Soon after sowing, the plastic containers were covered with parafilm (to minimize possible losses of humidity), after incubation in a germination chamber, BOD type, for $120 \mathrm{~h}$ at a temperature of $25 \pm 2{ }^{\circ} \mathrm{C}$, photoperiod (12 hours of light / 12 hours of dark) (BRASIL, 2009).

The soil used in the test was physico-chemically characterized according to the method recommended by the Brazilian Agricultural Research Company - EMBRAPA (1997) (Table 2).

The experimental design, doses and test procedures followed the same protocol as for the direct impact test.

\subsection{Evaluation and Statistical Analysis}


At the end of the experimental period the following parameters were evaluated: number of seeds germinated and not germinated, and length of roots (USEPA, 1996; OECD, 2003). The root length was measured with a digital caliper. Seeds showing a radicle protrusion were germinated (SOBRERO, RONCO, 2004).

For the determination of lethal effects in both tests, the LC50 was identified from comparison of the mean germination and/or graphical analysis. The sub-lethal effects were determined by identifying the no observed effect concentration (NOEC), which corresponds to the highest concentration/dose of toxicant that causes no statistically significant deleterious effect on the organisms during the exposure time under the test conditions; and the lowest observed effect concentration (LOEC), which is the lowest concentration/dose of toxicant that causes statistically significant deleterious effect on the organisms during the exposure time and test conditions (RONCO, BAEZ, GRANADOS, 2004). NOEC and LOEC were determined by comparison between the average length of the roots.

After physical examination and obtaining the means values of variables, these were submitted to the Lilliefors test of normality and Cochran-Bartlett test to determine homogeneity. The Scott-Knott test was used to analyze the significance between treatments at 5\% probability. To determine the correlation between the parameters and the concentration of pollutant (landfill leachate), we used the Pearson correlation coefficient ( $r$ ) and the $t$-test for significance at $p<0.05$ (ACHEN, 1977; ALDRICH, 1995).

The statistical analyzes were performed with the assistance of the program Assistat 7.7 (SILVA \& AZEVEDO, 2016), and the graphs constructed using Microsoft Excel 2013.

\section{Results and discussion}

The physical-chemical parameters presented in Table 1 allowed the classification of the landfill leachate as a young leachate (KURNIAWAN et al., 2010). It is also observed that when comparing the physical-chemical parameters of the leachate with the quality standard of effluent for release CONAMA 430/2011, this crude leachate does not have characteristics that allow its arrangement in the receiving body, defining it as pollutant potential under the physical-chemical optics. It is also noted that the parameters, salinity, aluminum and sodium present very high values. Studies on aluminum toxicity demonstrate the deleterious effects of this cation on plant metabolism (KOCHIAN, 2004). The exchangeable aluminum of the soils, for example, can reduce the germination, exerting decisive influences on the metabolism of the seeds (CRUZ et al., 1995).

It is observed (Table 2) that the $\mathrm{pH}$ value (7.50) represents a proximity to the neutrality. This characteristic guarantees the availability of the nutrients present in the soil. Silva and Ranno (2005) state that the problems of an acid soil are related to the lower availability of nutrients and, mainly, to the occurrence of $\mathrm{Al}^{3+}$ toxicity, whose severity is dependent on the $\mathrm{pH}$ value, but becomes practically null above of $\mathrm{pH} 5.5$ values. 
Table 1. Physico-chemical characterization of Barra Mansa-RJ's CTR landfill leachate.

CONAMA 430

Evaluated parameters Unit Observed values

Effluent discharge ${ }^{1}$

\begin{tabular}{|c|c|c|c|}
\hline pH (water) & ------- & 9.0 & $5.0-9.0$ \\
\hline Conductivity & $\mathrm{dS} \mathrm{m}^{-1}$ & 33.3 & N.D. \\
\hline COD & $\mathrm{mg} \mathrm{L}^{-1}$ & 5,592 & 120 \\
\hline Total dissolved solids & $\mathrm{mg} \mathrm{L}^{-1}$ & 23,600 & N.D. \\
\hline Salinity & $\mathrm{mg} \mathrm{L}^{-1}$ & 16,900 & N.D. \\
\hline Aluminium* & $\mathrm{mg} \mathrm{L}^{-1}$ & 7,625 & N.D. \\
\hline Ammonium** & $\mathrm{mg} \mathrm{L}^{-1}$ & 595.27 & 20.0 \\
\hline Cadmium* & $\mathrm{mg} \mathrm{L}^{-1}$ & 0.025 & 0.2 \\
\hline Calcium** & $\mathrm{mg} \mathrm{L}^{-1}$ & 95.38 & N.D. \\
\hline Lead $^{*}$ & $\mathrm{mg} \mathrm{L}^{-1}$ & 0.37 & 0.5 \\
\hline Chloride ${ }^{* *}$ & $\mathrm{mg} \mathrm{L}^{-1}$ & 857.50 & 250 \\
\hline Copper* & $\mathrm{mg} \mathrm{L}^{-1}$ & 0.17 & 1.0 \\
\hline Iron* & $\mathrm{mg} \mathrm{L}^{-1}$ & 13.66 & 15.0 \\
\hline Lithium** & $\mathrm{mg} \mathrm{L}^{-1}$ & 15.22 & 2.5 \\
\hline Magnesium** & $\mathrm{mg} \mathrm{L}^{-1}$ & 15.37 & N.D. \\
\hline Manganese* & $\mathrm{mg} \mathrm{L}^{-1}$ & 0.31 & 1.0 \\
\hline Niquel $^{*}$ & $\mathrm{mg} \mathrm{L}^{-1}$ & 0.48 & 2.0 \\
\hline Nitrate $^{* *}$ & $\mathrm{mg} \mathrm{L}^{-1}$ & 496.75 & 10 \\
\hline Potassium ${ }^{* *}$ & $\mathrm{mg} \mathrm{L}^{-1}$ & 694.46 & N.D. \\
\hline Sodium** & $\mathrm{mg} \mathrm{L}^{-1}$ & $1,172.46$ & N.D. \\
\hline Sulfate ${ }^{* *}$ & $\mathrm{mg} \mathrm{L}^{-1}$ & 846.00 & 250 \\
\hline Zinc* & $\mathrm{mg} \mathrm{L}^{-1}$ & 1.13 & 5.0 \\
\hline
\end{tabular}

COD - chemical oxygen demand; TDS - total dissolved solids; *Read via atomic absorption;

${ }^{* *}$ Read via ion chromatography; N.D. - not detected; ${ }^{1}$ Standard for effluent discharge into receiving waters; 
Table 2: Physical and chemical characterization of soil.

\begin{tabular}{|c|c|c|c|c|c|c|c|c|c|c|c|}
\hline $\mathrm{pH}$ & $\mathrm{Ca}^{2+}$ & $\mathrm{Mg}^{2+}$ & $\mathrm{K}^{+}$ & $\mathrm{Na}^{+}$ & $S$ & $\mathrm{Al}^{3+}$ & $\mathrm{H}^{+}+\mathrm{Al}^{3+}$ & $T$ & $\mathbf{P}$ & & C.org. \\
\hline $\mathrm{H}_{2} \mathrm{O}$ & 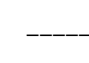 & 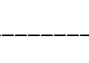 & 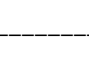 & $---\mathrm{cm}$ & $1_{c} \mathrm{dm}$ & & & & $--\mathrm{mg} \mathrm{dm}^{-3}$ & --_-_c & - \\
\hline 7.50 & 5.80 & 0.64 & 0.05 & 0.03 & 6.52 & 0.00 & 1.16 & 7.68 & 320.79 & 84.96 & 0.95 \\
\hline
\end{tabular}

$\mathrm{pH}-$ Hidrogenionic potential; $\mathrm{S}$ - sum of bases $(\mathrm{S}=\mathrm{Ca}+\mathrm{Mg}+\mathrm{Na}+\mathrm{K}+\mathrm{Al}) ; \mathrm{M}++\mathrm{Al} 3+$ - potential acidity; $\mathrm{T}$ - Value $\mathrm{T}(\mathrm{T}=\mathrm{S}+(\mathrm{M}+\mathrm{Al})) ; \% \mathrm{~V}$ - base saturation $(\mathrm{V}(\%)=(\mathrm{SB} \times 100) / \mathrm{T}) ; \mathrm{C}=$ organic carbon.

The analyzes carried out in the soil (Table 2) for the indirect impact test show that it has physico-chemical characteristics that guarantee an adequate environment for the development of the study, assuring that no changes in the characteristics of the species occur due to soil influence.

Comparing the data from Table 1 with the parameters studied for the species (Figure 1), it is observed that the introduction of landfill leachate exerts a great influence on them. The mean values of the percentage of germination as a function of the different doses of landfill leachate are shown in Figure 1. Significant differences between treatments were observed by Tukey's test $(\mathrm{p}<0.05)$.

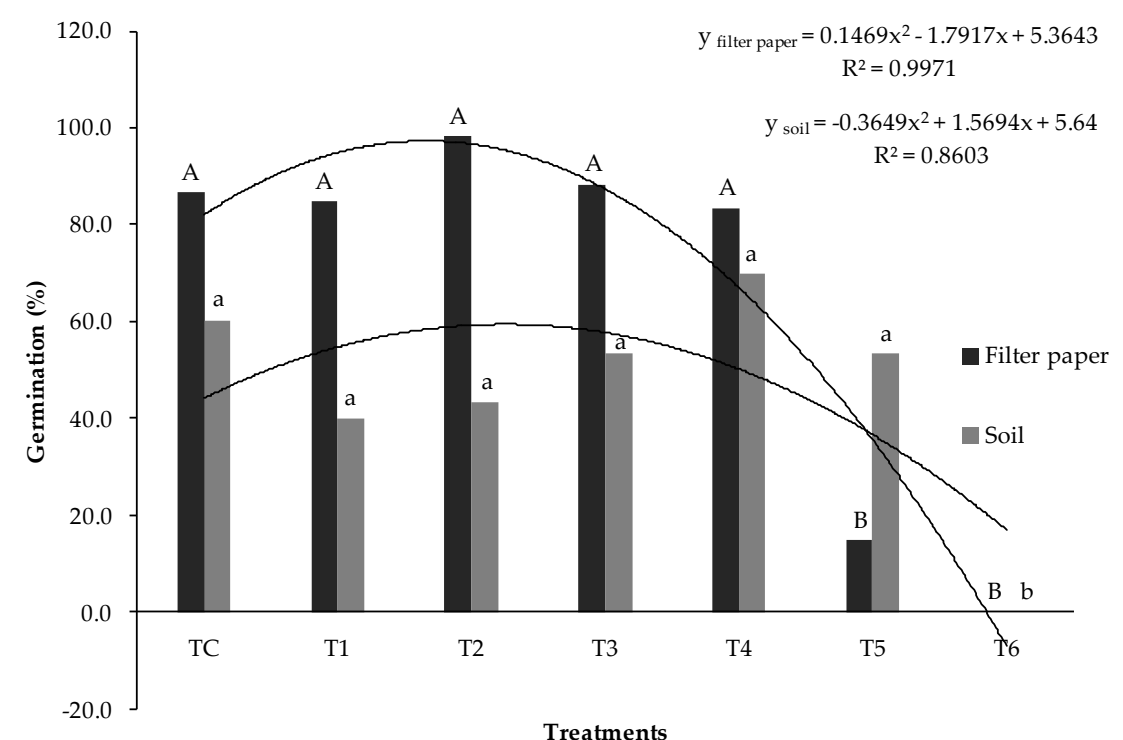

Figure 1. Average germination percentage $(\mathrm{G} \%)$ of cucumber submitted to the application of different doses of landfill leachate in two substrates, filter paper and soil. (Means followed by the same uppercase and lowercase letters in the column do not differ from each other by the Tukey test at $5 \%$ probability. TC: control treatment; T1 - dose $3.125 \%$ leachate $+96.875 \%$ deionized water; $\mathrm{T} 2$ - dose $6.25 \%$ leachate $+93.75 \%$ deionized water; T3 - dose $12.5 \%$ leachate $+87.5 \%$ deionized water; $\mathrm{T} 4$ - 25\% leachate solution $+75 \%$ deionized water; $\mathrm{T} 5$ - dose $50 \%$ leachate $+50 \%$ deionized water; T6 - 100\% leachate dose).

The germination test with the different substrates presented homogeneous but divergent results between the two media. When the substrate was filter paper, an abrupt reduction in germination was observed from the treatment with $50 \%$ of leachate (T4), which represented a reduction of approximately $83 \%$ in relation to the control treatment. However, for the soil substrate assay, a marked reduction occurs from the introduction of the $100 \%$ treatment in which the germination is zero. In both substrates it was not possible to determine the LC50 from the doses tested.

Considering the high salinity of landfill leachate (Table 1), it can be said that this characteristic associated with the presence of other components, such as aluminum, in the 
pollutant may have presented toxic potential on the germination of cucumber. Barbosa et al. (2013) identified high sensitivity of cucumber to aluminum toxicity.

Thode-Filho et al. (2017) evaluated the effect of landfill leachate on the germination of cabbage (Brassica oleracea var. Capitata) and identified a reduction of $61 \%$ in the germination percentage of the species with treatment of $6.25 \%$ in filter paper substrate. The same authors also defined that in a test with sandy soil, $100 \%$ reduction of the germination occurs in treatment with $25 \%$ of leachate. Comparing these results with the present study, it can be affirmed that the cucumber (Cucumis sativus) presents greater tolerance to the presence of the leachate, since under the same conditions the results occurred in the treatments $50 \%$ of leachate in substrate filter paper and $100 \%$ of leached.

Santos et al. (2016) state that salinity-tolerant plants exhibit selective ion absorption, that is, these plants can remove essential nutrients from the saline solution, where the concentration of non-essential ions is greater to regulate osmotic stress.

We adopted the evaluation of the length of the cucumber radicle to determine the sublethal effect of landfill leachate. The mean values of the radicle length as a function of the different doses of landfill leachate are shown in figure 2. Significant differences between treatments were observed by Tukey's test $(\mathrm{p}<0.05)$.

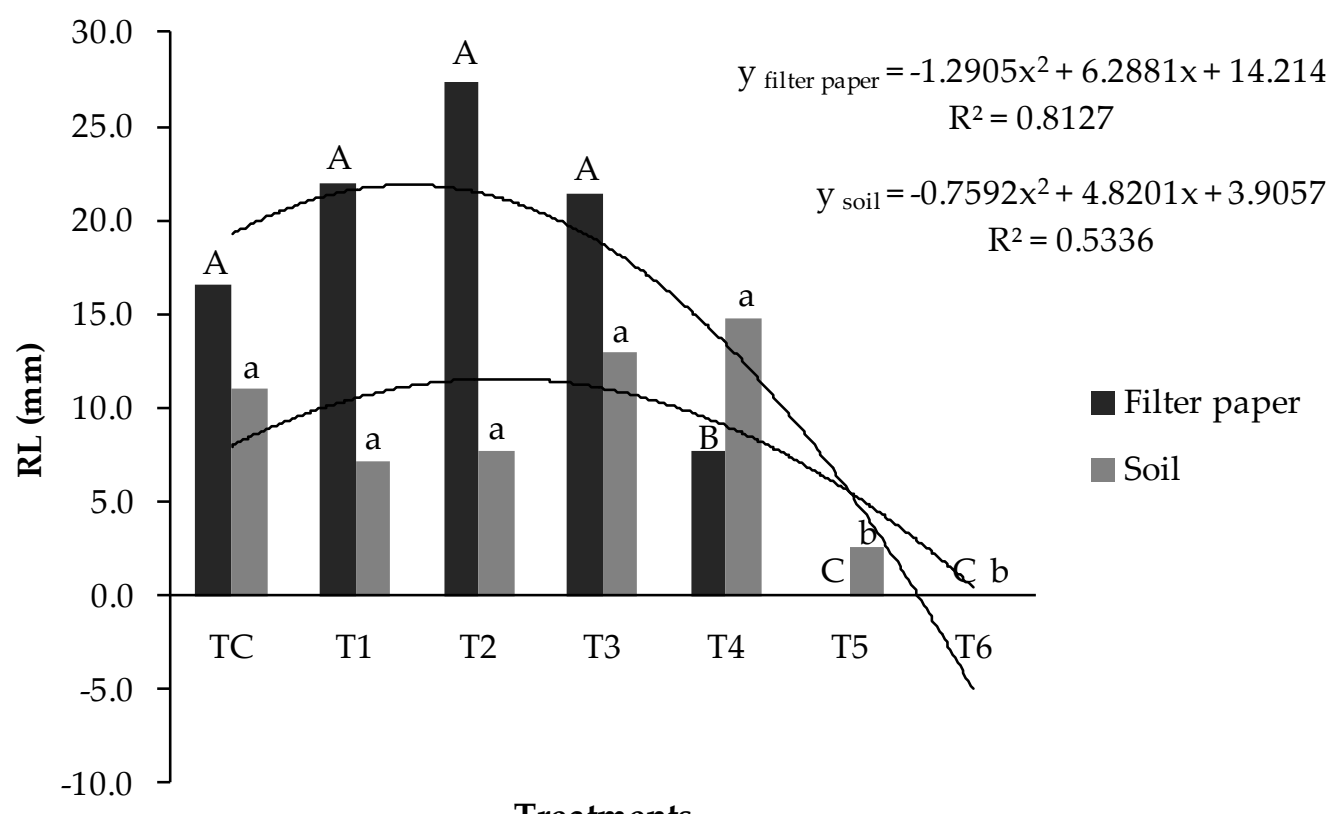

Figure 2. Average of root elongation of cucumber submitted to the application of different doses of landfill leachate in two substrates, filter paper and soil. (Means followed by the same uppercase and lowercase letters in the column do not differ from each other by the Tukey test at $5 \%$ probability. TC: control treatment; T1 - dose 3.125\% leachate $+96.875 \%$ deionized water; T2 - dose $6.25 \%$ leachate $+93.75 \%$ deionized water; T3 - dose $12.5 \%$ leachate $+87.5 \%$ deionized water; $\mathrm{T} 4-25 \%$ leachate solution $+75 \%$ deionized water; $\mathrm{T} 5-$ dose $50 \%$ leachate $+50 \%$ deionized water; T6 - 100\% leachate dose).

The analysis of the results (Figure 2) for the substrate filter paper allows to identify significant effect on the growth of the radicle from the treatment $25 \%$ (T4) when compared to the control treatment. Said treatment promoted an approximately $85 \%$ reduction in the parameter. It can be affirmed that the treatment corresponds to the value of CEO, concentration or dose of 
observed effect. It is also observed that the value of CENO is defined in the treatment with $12.5 \%$ of landfill leachate.

From the interpretation of the results of the test whose substrate is soil (Figure 2), it was possible to determine the treatment $50 \%$ (T5) as the one corresponding to the value of CEO and that the treatment caused a reduction of approximately $77 \%$. It is further obtained that the $25 \%$ (T3) treatment is defined as the CENO.

According to Ribeiro et al. (2009) salinity, is the situation of excess soluble salts, exchangeable sodium or both, which affects plant development. The most easily observed effect of salinity on plants is the reduction in growth due to nutritional imbalances (Ferreira et al., 2001). Nascimento et al. (2011) affirm that inhibition occurs in the growth of the root system under saline conditions. An excess of sodium salts, for example, cause widespread reduction of plant growth (Cavalcante et al., 2011).

Other elements added to the culture medium may interfere with the development of rootlets. According to Kochian et al. (2004), the main and first effectof aluminum on vegetables is reduction of root growth, the inhibition of cell stretching and expansion and then cell division. This effect of aluminum can be caused by the accumulation of lignin in the roots, stiffening the cell walls and preventing the root elongation (Peixoto et al., 2007).

Growth inhibition was also observed for the hypocotyl when the dosage of pollutant was increased. The mean values of the length of the cucumber hypocotyl (Cucumis sativus) as a function of the different doses of landfill leachate are shown in Figure 3. Significant differences between treatments were observed by the Tukey's test $(p<0.05)$.

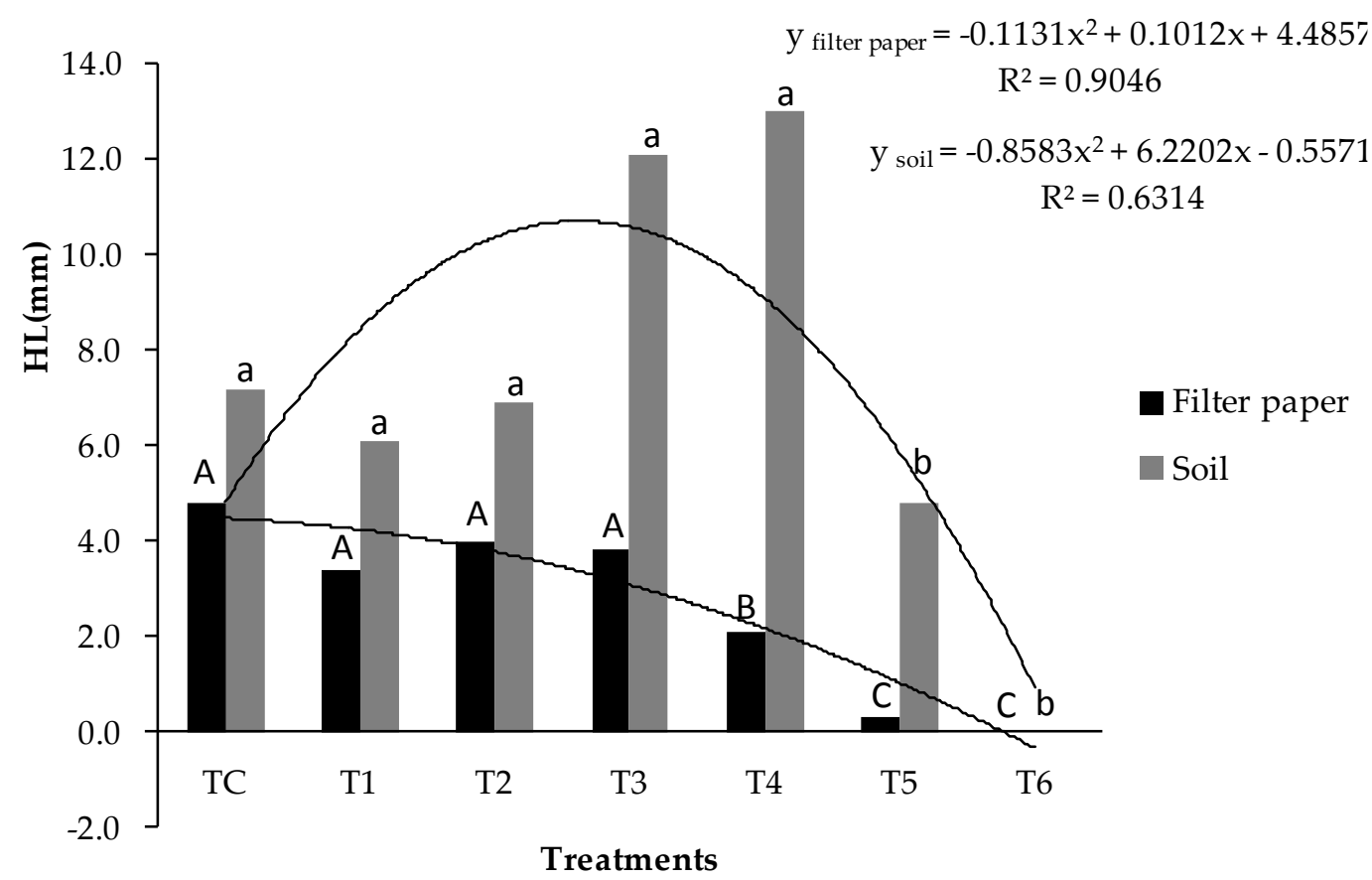

Figure 3. Average of hypocotyl length (HL) of cucumber submitted to the application of different doses of landfill leachate in two substrates, filter paper and soil. (Means followed by the same uppercase and lowercase letters in the column do not differ from each other by the Tukey test at 5\% probability. TC: control treatment; T1 - dose 3.125\% leachate $+96.875 \%$ deionized water; T2 - dose $6.25 \%$ leachate $+93.75 \%$ deionized water; T3 dose $12.5 \%$ leachate $+87.5 \%$ deionized water; T4 - 25\% leachate solution $+75 \%$ deionized water; $\mathrm{T} 5$ - dose $50 \%$ leachate $+50 \%$ deionized water; T6 - 100\% leachate dose). 
Also interpreting the development of cucumber, the comparison between hypocotyl length and root length confirms the significant negative influence of the landfill leachate on both substrates. Franco et al. (2017) studied the effect of landfill leachate on the germination and development of lettuce (Lactuca sativa L.) radicles, pointing out the greater effect due to high salinity of the pollutant. However, it is known that the effects of aluminum are intense on cucumber.

Steinkellner et al. (1998) and Lopez et al. (2008) state that germination bioassays with plants are advantageous because they are sensitive to several chemical compounds, such as pesticides, soil samples and organic substances, amongst others. However, the results obtained in the present study, it can be affirmed that it is important that the tests are also performed in different media.

\section{Conclusion}

The ecotoxicity tests performed in this study demonstrated a high tolerance of cucumber to the application of landfill leachate.

It was not possible to determine the LC50 value from the tested dosages. However, it was identified that the $50 \%$ and $100 \%$ doses for the filter and soil substrates caused a sudden inhibition in germination of approximately $83 \%$ and $100 \%$, respectively.

The NOEC and LOEC values for the substrate filter paper were identified in the treatments $12.5 \%$ and $25 \%$ respectively. Additionally, when the substrate was soil, treatments $25 \%$ and $50 \%$ corresponded to NOEC and LOEC.

\section{References}

ACHEN, Christopher H. Measuring Representation: Perils of the Correlation Coefficient. American Journal of Political Science. 1977; 21 (4): 805-815.

ADAMS, W.J., ROWLAND, C.D. Aquatic toxicology Test Methods. In HOFFMAN, D.J; RATTNER, B.A.; BURTON Jr, G.A.; CAIRNS Jr, J. (Editores) Handbook of Ecotoxicology, Washington, D.C.: Lewis Publishers. 2.ed. p. $32-58,2002$.

ALDRICH, J.H. Correlations Genuine and Spurious in Pearson and Yule. Statistical Science. 1995; 10 (4): $364-$ 376.

ALMEIDA, C., FERREIRA, D., SECO, F., IRIA, I., JESUS, J. Análise Ecotoxicológica de Águas Residuais de Uma Indústria Metalúrgica. XI CNEA - Congresso Nacional de Engenharia do Ambiente. Lisboa, 2011.

ARAGÃO, M.A., ARAÚJO, R.P.A. Métodos de ensaios de toxicidade com organismos aquáticos. In ZAGATTO, P.A.; BERTOLETTI, E. (Editores). Ecotoxicologia Aquática: Princípios e Aplicações, São Carlos, São Paulo: RIMA, 2008. P. 117 - 147.

BARBOSA, R.M., GALTER, I.N., PEREIRA, C.L., MARTINS, L.A.R., SILVA, K.S.. ANDRADE-VIEIRA, L.F. Eficiência do pepino como modelo em bioensaios de fitotoxicidade. Resumos Expandidos do I CONICBIO / II CONABIO / VI SIMCBIO (v.2) Universidade Católica de Pernambuco - Recife - PE - Brasil - 11 a 14 de novembro de 2013.

BRASIL. Ministério da Agricultura, Pecuária e Abastecimento. Regras para análise de sementes / Ministério da Agricultura, Pecuária e Abastecimento. Secretaria de Defesa Agropecuária. - Brasília : Mapa/ACS, 2009. 399 p. 
CARVAlHO, A.L., MATOS, A.T., HAMAKAWA, P.J., AZEVEDO, R. F. Produção de percolado por resíduos sólidos urbanos de diferentes idades, na presença de resíduos da construção civil e sob recirculação. Engenharia na Agricultura, v.14, n.2, p.131-138, 2006.

CAVALCANTE, L.F., CORDEIRO, J.C., NASCIMENTO, J.A.M., CAVALCANTE, Í.H.L., DIAS, T. J. Fontes e níveis da salinidade da água na formação de mudas de mamoeiro cv. Sunrise solo. Semina: Ciências Agrárias, v.31, p.12811290, 2011.

COSTA, C.R., OLIVI, P., BOTTA, C.M., ESPINDOLA. E.L.G. A toxicidade em ambientes aquáticos: discussão e métodos de avaliação. Quim Nova. 31 : 1820-1830, 2008.

CRUZ, M.S., PÉREZ-URRIA, E., MARTIN, L., AVALOS, A., VICENTE, C. Factors affecting germination of Canavalia brasiensis, Leucena loucocephala, Clitoria ternata and Calopogonio mucunoides seeds. Seed Science \& Technology, Zurich, v.23, n.2, p.447-454, 1995.

EMPRESA BRASILEIRA DE PESQUISA AGROPECUÁRIA. Manual de métodos de análises de solos. Rio de Janeiro: Embrapa-CNPS. 1997. 212p

FISKESJÖ, G. The Allium test as a standard in environmental monitoring. Hereditas 102: 99-112, 1985.

FLOHR. L., BRENTANO, D.M., CARVALHO-PINTO, C.R.S. de, MACHADO, V. G., MATIAS, W.G. Classificação de resíduos sólidos industriais com base em testes ecotoxicológicos utilizando Daphnia magna: uma alternativa. Biotemas, Florianópolis, v. 18, n. 2, p. 7-18, 2005.

FRANCO, H.A., MARQUES, M.R. da C., BRAGA, C.F., IZIDORIO, A. de S., THODE-FILHO, S. Effect of landfill leachate on germination of lettuce seeds (Lactuca sativa L.). Electronic Journal of Management, Education and Environmental Technology-REGET, (2017). [no prelo]

INSTITUTO DE PESQUISAS TECNOLÓGICAS DO ESTADO DE SÃO PAULO (IPT). Lixo Municipal: manual de gerenciamento integrado. São Paulo: IPT/CEMPRE. 1995. 278p.

KOCHIAN, L.V., HOEKENGA, O.A., PIÑEROS, M.A. How do crop plants tolerate acid soils? Mechanisms of aluminum tolerance and phosphorous efficiency. Annual Review of Plant Physiology and Molecular Biology, v.55, p. 459-493, 2004.

KURNIAWAN, T.A., LO, W., CHAN, G., SILLANPAA, M.E.T. Biological processes for treatment of landfill leachate. Journal of Environmental Monitoring, v. 12, p. 2032-2047, 2010. Disponível em: $<$ http://pubs.rsc.org/en/content/articlelanding/2010/em/c0em00076k\#!divAbstract>. Acesso em: 14 abr. 2017.

LOPEZ, G.D., CAMBERO, J.P.G., CALVO, A.C. Germination of Lactuca sativa seeds as pre-screening in toxicology studies in higher plants. Toxicology Letters 180S, S32-S246, 2008.

LOPES, P.R.M., MONTAGNOLLI, R.N., DOMINGUES, R.F., BIDOIA, E.D. Toxicity and biodegradation in sandy soil contaminated by lubricant oils. Bull. Environ. Contam.Toxicol. 84 (4), 454-458. 2010.

NASCIMENTO, J.A.M., CAVALCANTE, L.F., SANTOS, P.D. dos, SILVA, S.A. da; VIEIRA, M. da S., OLIVEIRA, A.P. de. Efeito da utilização de biofertilizante bovino na produção de mudas de pimentão irrigadas com água salina. Revista Brasileira Ciências Agrárias, v. 6, n. 2, p. 258-264, 2011.

ORGANIZATION FOR ECONOMIC COOPERATION AND DEVELOPMENT - OECD - Terrestrial Plant Test: 208: Seedling Emergence and Seedling Growth Test. Guideline for the Testing of Chemicals Proposal for Updating Guideline 208, 2003.

OMAR, H., ROHANI, S. Treatment of landfill waste, leachate and landfill gas: A review. Front. Chem. Sci. Eng. 9(1): 15-32, 2015. 
PEIXOTO, P.H.P., PIMENTA, D.S., CAMBRAIA, J. Alterações morfológicas e acúmulo de compostos fenólicos em plantas de Sorgo sob estresse de Alumínio. Bragantia, Campinas. V.66, n.1, p. 17 - 25, 2007.

RIBEIRO, M.R., BARROS, M.F.C., FREIRE, M.B.G.S. Química dos solos salinos e sódicos. In: MELO, V. F.; ALLEONI, L. R. F. (Ed.). Química e mineralogia do solo, 1. ed. Viçosa, MG: SBCS, p.449-484. 2009.

RONCO, A., BÁEZ, M.C.D., GRANADOS, Y.P. Em Ensayos Toxicológicos y Métodos de Evaluación de Calidad de Aguas - Estandarización, Intercalibración, Resultados y Aplicaciones; Morales, G. C., ed.; Centro Internacional de Investigaciones para el Desarrollo: Ottawa, 2004, cap. 1.

SALEM, Y., HAMOURI, K., DJEMAA, R., ALOIS, K. Evaluation of landfill leachate pollution and treatment. Desalination 220, 108-114. 2008.

SANTOS, J.B., GHEYI, H.R., LIMA, G.S., XAVIER, D.A., CAVALCANTE, L.F., CENTENO, C.R.M. Morfofisiologia e produção do algodoeiro herbáceo irrigado com águas salinas e adubado com nitrogênio. Comunicata Scientiae, v.7, n.1, p.86-96, 2016.

SILVA, F. de A. S., AZEVEDO, C.A.V. de. The Assistat Software Version 7.7 and its use in the analysis of experimental data. Afr. J. Agric. Res, v.11, n.39, p.3733-3740, 2016. DOI: 10.5897/AJAR2016.11522.

SILVA, L.S. da, RANNO, S.K. Calagem em solos de várzea e a disponibilidade de nutrientes na solução do solo após o alagamento. Ciência Rural, v. 35, n. 5, set-out, 2005.

SOBRERO, M. C., RONCO, A. Ensayo de toxicidad aguda con semillas de lechuga (Lactuca sativa L.). In: Morales, G. C. Ensayos toxicológicos y métodos de evaluación de calidad de águas: Estandarización, Intercalibración, resultados e ya aplicaciones, IMTA, p. 63-72, 2004.

STEINKELLNER, H., MUN-SIK, K., HELMA, C., ECKER, S., MA, T.H., HORAK, O., KUNDI, M., KNASMUÈLLER, S. Genotoxic Effects of Heavy Metals: Comparative Investigation With Plant

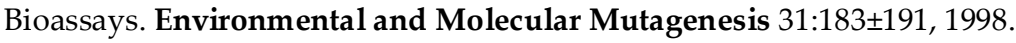

THODE-FILHO, S., MARTINS, G.M. de O., MUSSEL, Y.L., MARQUES, M.R. da C., FRANCO, H.A. Ecotoxicological evaluation of the application of landfill leachate on the germination of Cabbage (Brassica oleracea var. capitata). Electronic Journal of Management, Education and Environmental TechnologyREGET, (2017). [no prelo]

UNITED STATES ENVIRONMENTAL PROTECTION AGENCY - US EPA - Seed Germination/ Root Elongation Toxicity Tests. Ecological Effects, Tests Guidelines, 1996.

USEPA - UNITED STATES ENVIRONMENTAL PROTECTION AGENCY. SW-846 EPA Method 3051A. Microwave assisted acid digestion of sediments, sludges, soils and oils. Test Methods for Evaluating Solid Waste. 3rd Update. Washington, DC, 1998. 